\title{
Examination of Flood Characteristics at Selected Streamgages in the Meramec River Basin, Eastern Missouri, December 2015-January 2016
}

\author{
By Robert R. Holmes, Jr., Todd A. Koenig, Paul H. Rydlund, and David C. Heimann
}

\section{Overview}

Heavy rainfall resulted in major flooding in the Meramec River Basin in eastern Missouri during late December 2015 through early January 2016. Cumulative rainfall from December 14 to 29,2015 , ranged from 7.6 to 12.3 inches at selected precipitation stations in the basin with flooding driven by the heaviest precipitation (3.9-9.7 inches) between December 27 and 29, 2015 (National Centers for Environmental Information, 2016). Financial losses from flooding included damage to homes and other structures, damage to roads, and debris removal. Eight of 11 counties in the basin were declared a Federal Disaster Area (Nelson, 2016).

The U.S. Geological Survey (USGS), in cooperation with the U.S. Army Corps of Engineers and St. Louis Metropolitan Sewer District, operates multiple streamgages along the Meramec River and its primary tributaries including the Bourbeuse River and Big River (fig. 1). The period of record for streamflow at streamgages in the basin included in this report ranges from 24 to 102 years (table 1). Instrumentation in a streamgage shelter automatically makes observations of stage using a variety of methods (submersible pressure transducer, non-submersible pressure transducer, or non-contact radar). These observations are recorded autonomously at a predetermined programmed frequency (typically either 15 or 30 minutes) dependent on drainage-area size and concomitant flashiness of the stream. Although stage data are important, streamflow data are equally or more important for streamflow forecasting, water-quality constituent loads computation, flood-frequency analysis, and flood mitigation planning. Streamflows are computed from recorded stage data using an empirically determined relation between stage and streamflow termed a "rating." Development and verification of the rating requires periodic onsite discrete measurements of streamflow throughout time and over the range of stages to define local hydraulic conditions.

The purpose of this report is to examine characteristics of flooding that occurred in the Meramec River Basin in December 2015-January 2016 including peak stages, peak streamflows, and the flood-frequency statistics associated with the peak flows. A comparison between the December 2015-January 2016 flood and a similar flood in December 1982 in the Meramec River Basin also is included.

Homes flooded by the Meramec River in Pacific, Missouri, December 29, 2015. Photograph by Doug Moore, St. Louis Post-Dispatch, used with permission.






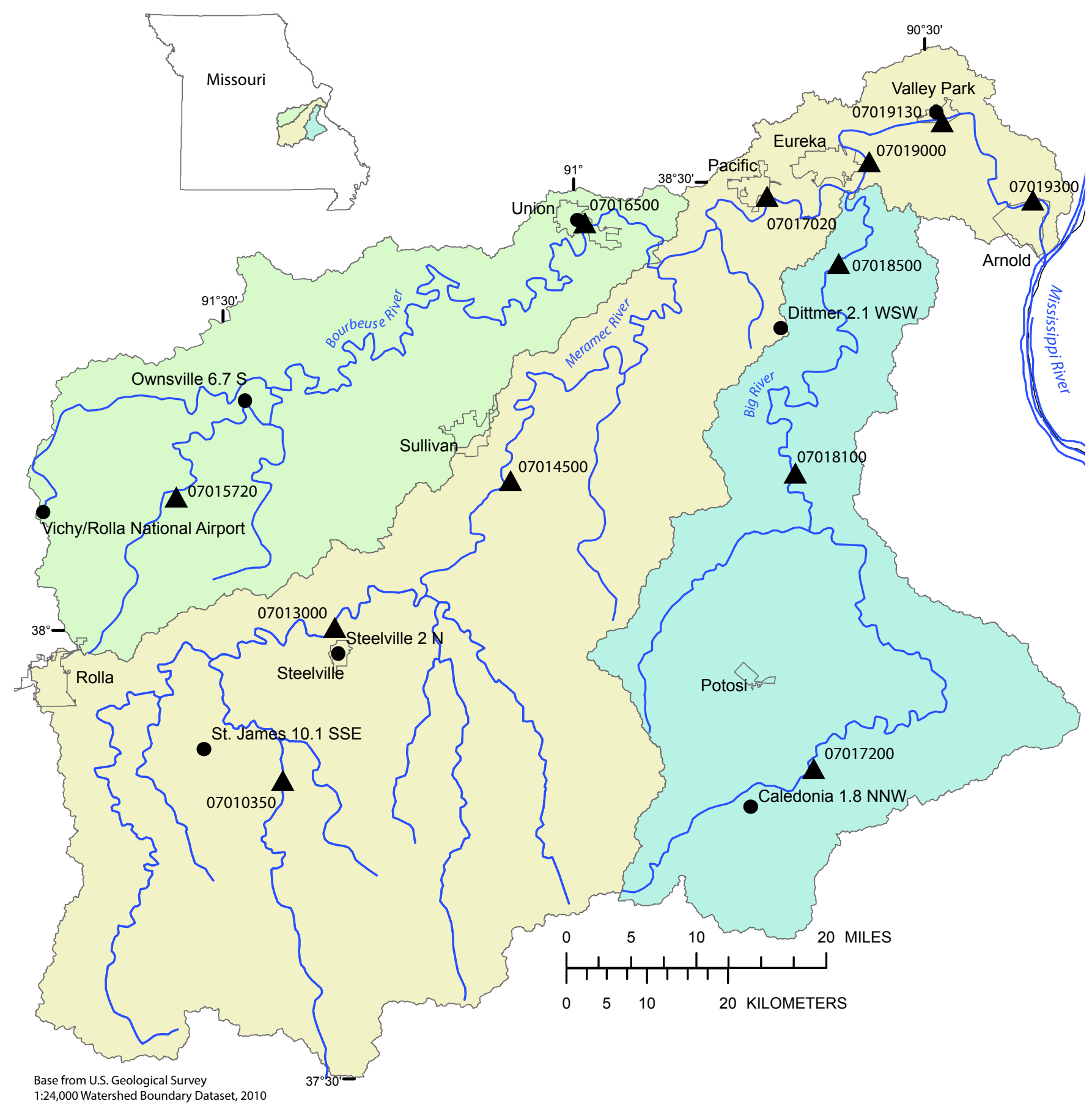

\section{EXPLANATION}

07010350

$\Delta \quad$ U.S. Geological Survey streamgage and number

Meramec River Basin

- National Climatic Data Center precipitation station and name

$\square$ Bourbeuse River Basin

$\square$ Cities

Big River Basin

Main-stem Meramec River Basin

Figure 1. Meramec River Basin including major tributaries-Bourbeuse River and Big River. 


\section{Characteristics of December 2015- January 2016 Flooding in the Meramec River Basin}

\section{Flood Summary Data by Streamgage}

Streamflow hydrographs for December 20, 2015January 7, 2016, at selected main-stem and tributary streamgages in the Meramec River Basin show the upstream to downstream increase in streamflow magnitude and the temporal progression of streamflow peaks in the basin (fig. 2). There were peak stages during the December 2015-January 2016 flood in the basin that exceeded the period-of-record peak stage at selected streamgages (table 1). Of these selected streamgages, no peak streamflow during the December 2015January 2016 flood exceeded the peak streamflow for the period of record, but the peaks generally were ranked in the top five at the selected stations (table 1). The streamgages at which the December 2015-January 2016 flood did not rank in the top five of streamflow peaks during the period of record were in the upstream portion of the basin. These streamgages included the Meramec River near Steelville, Missouri, and the Big River at Irondale, Missouri, but the December 2015 peaks at these streamgages still ranked in the top 10 for peak streamflow during the period of record.

Table 1. Peak stage and streamflow data at selected streamgages in the Meramec River Basin for the flood of December 2015-January 2016 (available online at http://dx.doi. org/10.3133/ofr20161140).
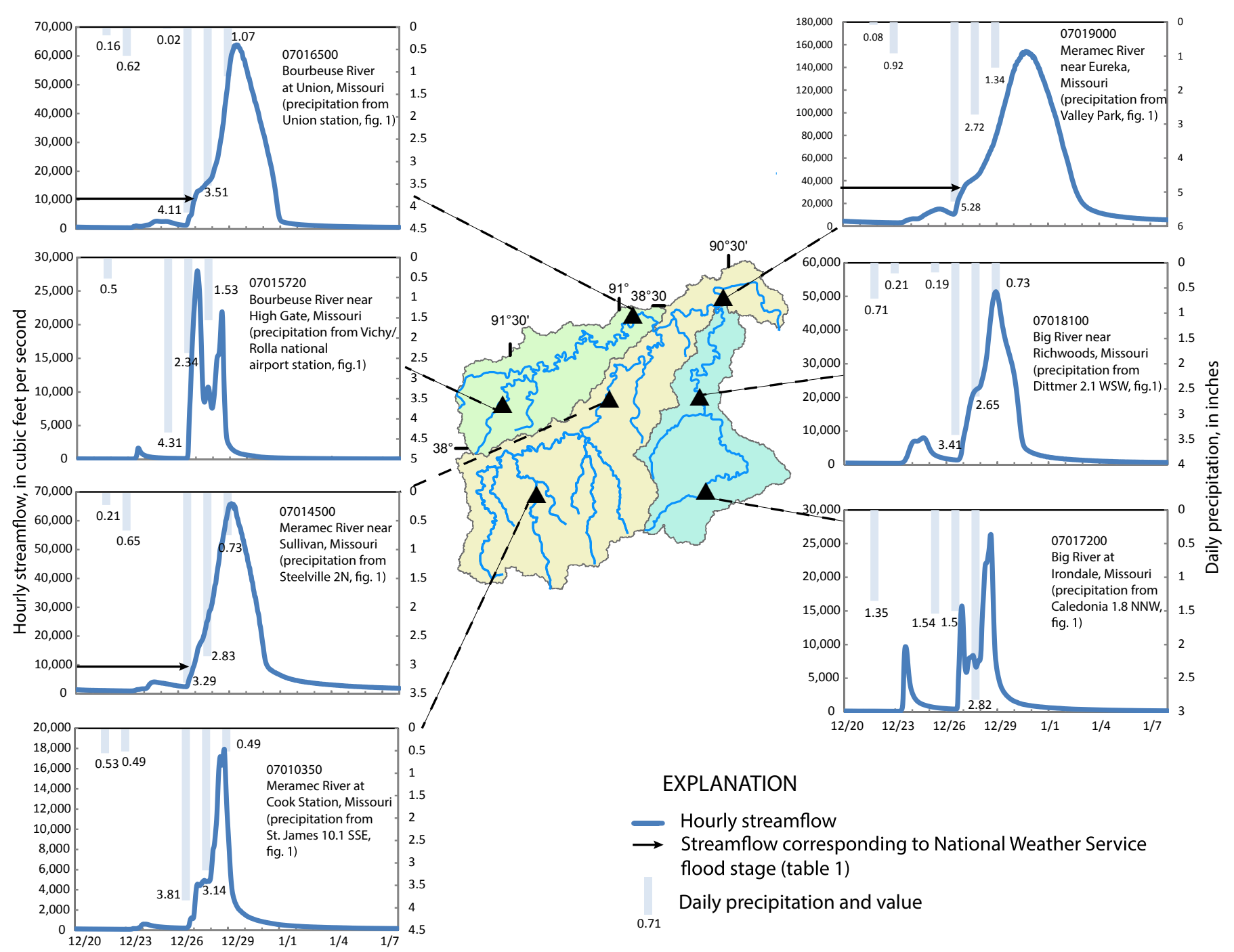

Figure 2. Streamflow hydrographs and precipitation distributions for selected streamgages and precipitation stations within the Meramec River Basin, December 20, 2015-January 7, 2016. 


\section{Comparison of 1982 and 2015 Floods}

The heavy rainfalls that occurred in December 2015 in the Meramec River Basin were similar in timing and magnitude to those in December 1982, which also resulted in widespread flooding in the basin (Sauer and Fulford, 1983). Both events were associated with an El Niño climatic pattern (National Oceanic and Atmospheric Administration, 2016), which is characterized by warm ocean temperatures in the equatorial Pacific Ocean and increased rainfall across the southern tier of the United States (Earth Systems Research Laboratory, 2016). A comparison of peak stages and streamflows during the December 1982 and December 2015 floods at selected locations within the Meramec River Basin is shown in table 2. The December 1982 flood peak streamflows were greater than the December 2015 flood peak streamflows at upstream Meramec River and Bourbeuse River streamgages (first four streamgages listed in table 2), whereas the December 2015 streamflows were greater than December 1982 peak flows at the Meramec River near Eureka and all Big River streamgages. Streamflows in the Bourbeuse and upper Meramec River Basins were 1,700 to 21,300 cubic feet per second $\left(\mathrm{ft}^{3} / \mathrm{s}\right)$ higher in December 1982 compared to December 2015, whereas flows in the lower Meramec River and Big River Basins were 8,600 to $17,000 \mathrm{ft}^{3} / \mathrm{s}$ higher in December 2015 compared to December 1982.
For the upstream streamgages on the Meramec and Bourbeuse Rivers (first three streamgages listed in table 2), the December 1982 peak stages were higher than the December 2015 flood stages as would be expected with higher streamflows and when the hydrodynamic conditions of the channel (which would affect the relation between stage and streamflow) have not changed appreciably between floods. The December 1982 peak stages at the upstream Bourbeuse and Meramec River streamgages were 0.72 to 1.25 feet higher than in December 2015. For the downstream streamgages on each river (table 2), the 1982 flood peak stages were 0.51 to 4.24 feet lower than the December 2015 flood, and the December 1982 streamflows generally were lower than in December 2015. The exception was the Bourbeuse River at Union, Missouri, streamgage with a peak stage that was 0.51 feet higher in December 2015 than in December 1982 despite a lower peak streamflow. A higher peak stage for a lower peak streamflow is the result of changing hydrodynamic conditions of the channel, either from downstream backwater effects from tributaries or the Meramec River, the timing of the flood wave, or physical changes to the downstream channel.

Table 2. Comparison of peak stages from the December 1982 and December 2015 floods at selected streamgages in the Meramec River Basin (available online at http://dx.doi.org/10.3133/ ofr20161140).

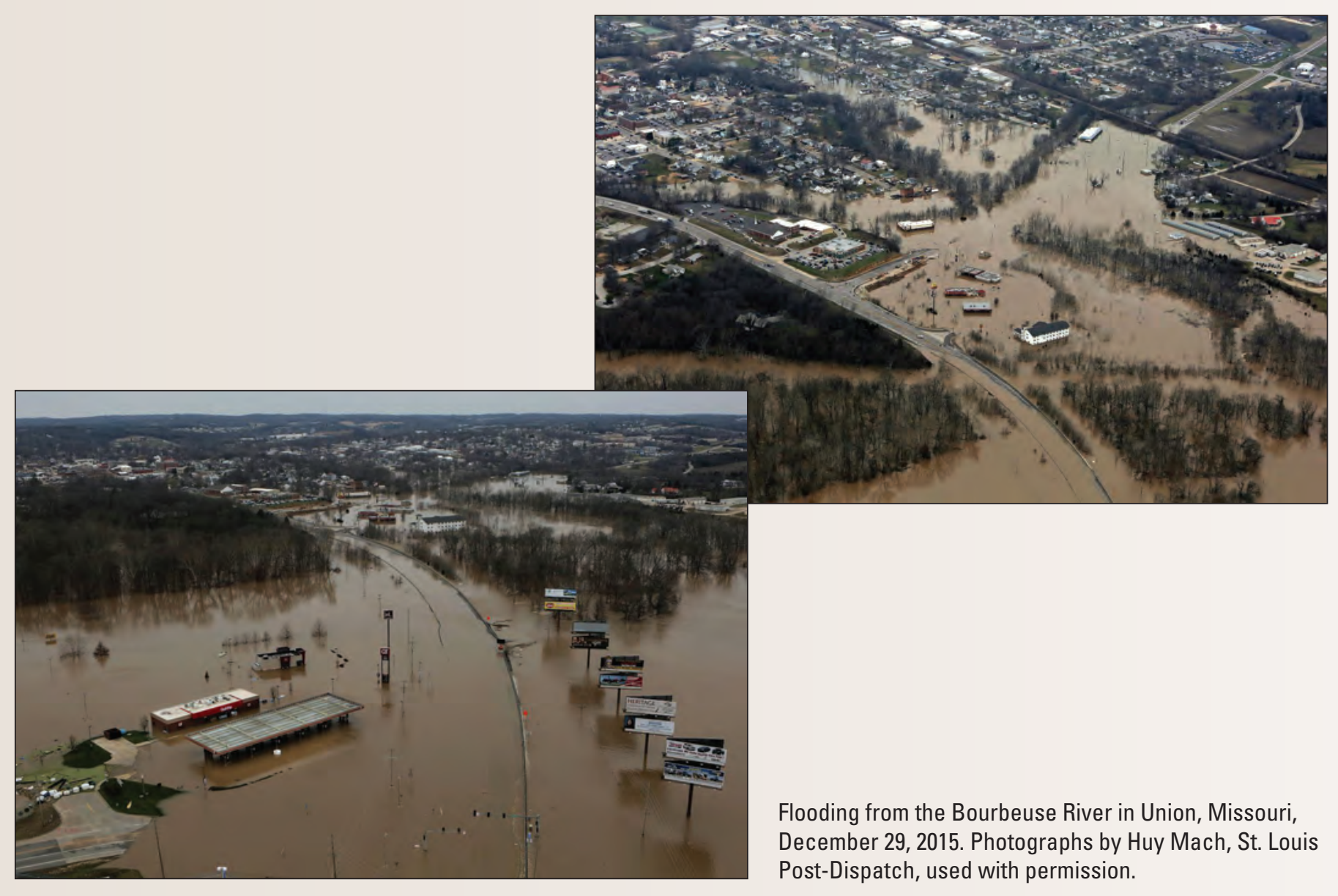




\section{Flood-Frequency Analyses}

Flood-frequency estimates for the Bourbeuse River at Union, Missouri, and the Meramec River near Eureka, Missouri, are shown in table 3. In the past, flood-frequency estimates have been presented in terms of the recurrence interval, which represents the average number of years between occurrences of a streamflow of equal or greater magnitude. This term, however, often results in a misunderstanding that a 100-year flood, once it has occurred, will not occur again for another 99 years, which is not necessarily true. A 100-year flood means that, if all things remain the same in the basin (for example, land use and climate conditions), the observed annual floods during thousands of years would average around 100 years between events of this magnitude. For example, sometimes it could be 200 years and other times it could be 30 years between " 100 -year" magnitude flood events during those thousands of years. The term annual exceedance probability (AEP) is now more commonly used to refer to floodfrequency estimates because it more clearly conveys that the flood-frequency estimates are probabilistic in nature. The AEP is the probability that the streamflow of a certain magnitude will be equaled or exceeded in any year and is the reciprocal of the recurrence interval. A 100-year flood streamflow, for example, is the same as a streamflow having a $0.01 \mathrm{AEP}$, or a flood streamflow with a 1-percent chance of occurring in any year.
The current (2016) standard methodology for the determination of flood-frequency studies is Bulletin 17B of the Interagency Advisory Committee on Water Data (U.S. Interagency Advisory Committee on Water Data, 1982). The Bulletin 17B method fits a log-Pearson Type III distribution curve to the logarithms of annual peak discharges at a given station using the method-of-moments to compute a mean, standard deviation, and station skew of the log-transformed peak flow data. The user has the option to weigh the individual station skew estimate with a generalized/regional skew estimate, which typically improves the accuracy because skews tend to follow regional trends. At the time of this report, modest changes to Bulletin 17B, recommended by the Advisory Committee on Water Information (http://acwi.gov), are being drafted into Bulletin 17C (http://acwi.gov/hydrology/Frequency/b17c/bulletin17c_draft_for_public_review.pdf). Modifications include the adoption of a generalized method-of-moments estimator, known as the expected moments algorithm (EMA) procedure (Cohn and others, 1997), and a generalized version of the Grubbs-Beck test for low outliers (Cohn and others, 2013). The EMA is an updated method for fitting the log-Pearson Type III frequency distribution that has been shown to be a more effective means of incorporating historical peak streamflow information into a flood-frequency analysis.

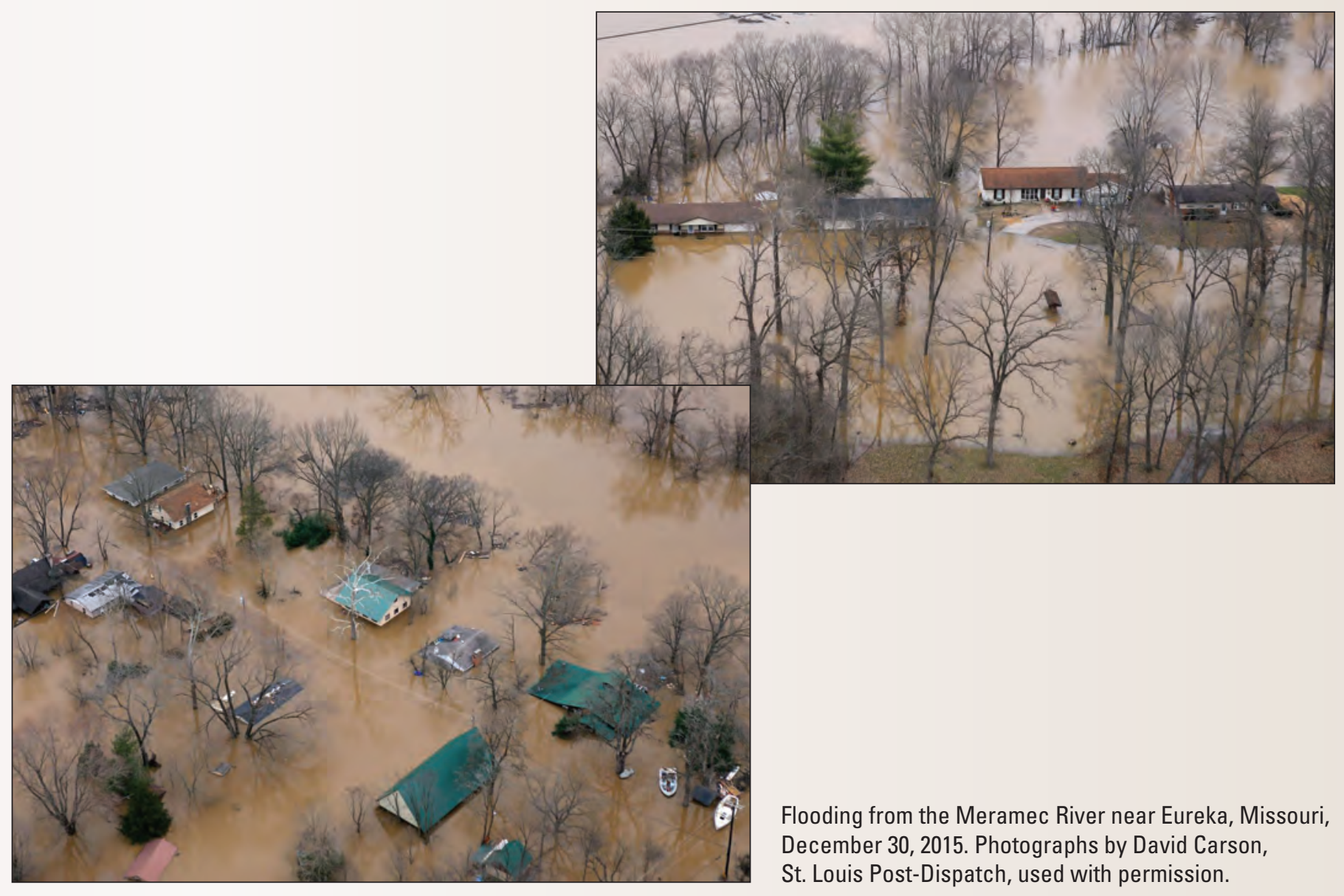


The USGS computer program PEAKFQ (version 7.1; Flynn and others, 2006) was used to compute the flood-frequency estimates for the Bourbeuse River at Union, Missouri, and the Meramec River near Eureka, Missouri. The program automates many of the flood-frequency analyses procedures, including identifying and adjusting for high and low outliers and historical periods, and fitting the log-Pearson Type III distribution to the streamflow data. The program includes the EMA procedure for flood-frequency analysis and multiple Grubbs-Beck outlier screening (Veilleux and others, 2013). The PEAKFQ program and associated documentation are available at http://water.usgs.gov/software/peakfq.html.

The estimated AEP corresponding to the December 2015 flood at the Bourbeuse River at Union, Missouri, is 0.52 percent (recurrence interval of 191 years), with the uncertainty of this estimate, expressed by the 66.7-percent confidence interval for the true exceedance probability, being from 0.7 (recurrence interval of 143 years) to 3.1 percent (recurrence interval of 32 years) (table 3). The 66.7-percent confidence interval for the AEP is a non-parametric estimate based on a flood of a given rank within a specified period of record. These confidence intervals are not centered about the interpolated AEP estimate. Consequently, the range of the confidence interval may exclude the AEP estimate. The 2-percent, 1-percent, 0.5-percent, and 0.2-percent AEP flood quantiles for each streamgage, along with the 95-percent confidence interval range for each quantile, are also shown in table 3. The observed peak streamflow of $64,000 \mathrm{ft}^{3} / \mathrm{s}$ falls within the estimated 1-percent annual exceedance flow of $55,700 \mathrm{ft}^{3} / \mathrm{s}$ and the estimated 0.5 -percent annual exceedance flow of $64,400 \mathrm{ft}^{3} / \mathrm{s}$ based on 103 years of peak record used in the analysis.

Table 3. Summary of peak stages, streamflows, and floodfrequency estimates for the December 2015 flood at selected Meramec River Basin streamgages (available online at http:// dx.doi.org/10.3133/ofr20161140).

The estimated AEP corresponding to the December 2015 flood at the Meramec River near Eureka, Missouri, is 1.1 percent (recurrence interval of 91 years). A 66.7-percent confidence interval for the true annual exceedance probability of the flood extends from 0.7 (recurrence interval of 143 years) to 3.2 percent (recurrence interval of 31 years). The observed peak streamflow of $162,000 \mathrm{ft}^{3} / \mathrm{s}$ falls within the estimated 2-percent annual exceedance flow of $140,000 \mathrm{ft}^{3} / \mathrm{s}$ and the estimated 1-percent annual exceedance flow of $165,000 \mathrm{ft}^{3} / \mathrm{s}$ based on 99 years of peak record used in the analysis.
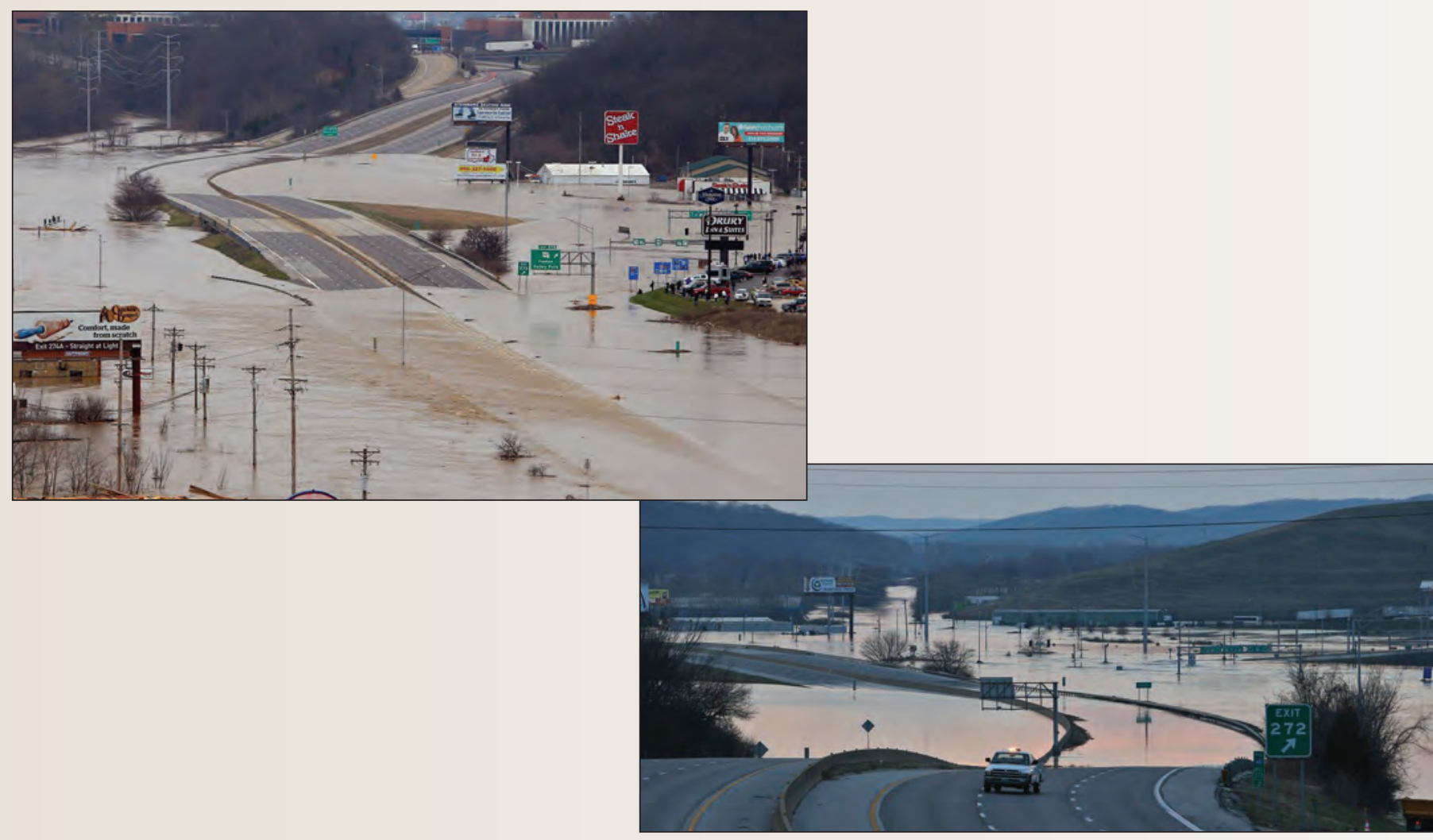

Flooding from the Meramec River in Valley Park, Missouri. Upper left photograph taken December 30, 2015, by David Carson, St. Louis Post-Dispatch, used with permission. Lower right photograph taken December 31, 2015, by J.B. Forbes, St. Louis Post-Dispatch, used with permission. 


\section{References Cited}

Cohn, T.A., England, J.F., Berenbrock, C.E., Mason, R.R., Stedinger, J.R., and Lamontagne, J.R., 2013, A generalized Grubbs-Beck test statistic for detecting multiple potentially influential low outliers in flood series: Water Resources Research, v. 49, no. 8, p. 5047-5058.

Cohn, T.A., Lane, W.L., and Baier, W.G., 1997, An algorithm for computing moments-based flood quantile estimates when historical flood information is available: Water Resources Research, v. 33, no. 9, p. 2089-2096.

Earth Systems Research Laboratory, 2016, Multivariate ENSO Index (MEI): National Oceanic and Atmospheric Administration, accessed May 18, 2016, at http://www.esrl.noaa. gov/psd/enso/mei/.

Flynn, K.M., Kirby, W.H., and Hummel, P.R., 2006, User's manual for program PeakFQ, Annual flood frequency analysis using Bulletin 17B guidelines: U.S. Geological Survey Techniques and Methods, book 4, chap. B4, 42 p.

National Centers for Environmental Information, 2016, Data access: accessed May 16, 2016, at http://www.ncdc.noaa. gov/data-access.

National Oceanic and Atmospheric Administration, 2016, Explaining El Niño-Impacts: El Nino Theme Page, Pacific Marine Environmental Laboratory, accessed May 18, 2016, at http://www.pmel.noaa.gov/elnino/impacts-of-el-nino.

Homes flooded by the Meramec River in Arnold, Missouri, December 31, 2015. Photograph by David Carson, St. Louis Post-Dispatch, used with permission.
National Weather Service, 2016, Advanced hydrologic prediction service: National Oceanic and Atmospheric Administration, accessed May 16, 2016, at http://water.weather.gov/ ahps/.

Nelson, Alisa, 2016, FEMA approves Nixon's request to expand Missouri's federal disaster declaration: Missourinet, accessed May 18, 2016, at http://www.missourinet. com/2016/02/10/fema-approves-nixons-request-to-expandmissouris-federal-disaster-declaration/.

Sauer, V.B., and Fulford, J.M., 1983, Floods of December 1982 and January 1983 in central and southern Mississippi River Basin: U.S. Geological Survey Open-File Report 83-213, $41 \mathrm{p}$.

U.S. Army Corps of Engineers, 2016, River and reservoir daily report, St. Louis District: accessed May 13, 2016, at http://mvs-wc.mvs.usace.army.mil/dresriv.html.

U.S. Geological Survey, 2016, National Water Information System: U.S. Geological Survey Water Data for Missouri, accessed May 13, 2016, at http://waterdata.usgs.gov/mo/ nwis/nwis.

U.S. Interagency Advisory Committee on Water Data, 1982, Guidelines for determining flood flow frequency (revised): U.S. Geological Survey, Office of Water Data Coordination, Bulletin 17B, 28 p., 14 app., and 1 pl.

Veilleux, A.G., Cohn, T.A., Flynn, K.M., Mason, R.R., and Hummel, P.R., 2013, Estimating magnitude and frequency of floods using the PeakFQ 7.0 program: U.S. Geological Survey Fact Sheet 2013-3108, 2 p. 


\title{
For more information concerning this publication, contact:
}

\author{
Chief, USGS Office of Surface Water \\ 415 National Center \\ 12201 Sunrise Valley Drive \\ Reston, VA 20192 \\ (703) 648-5301
}

Or visit the Office of Surface Water Web site at:

http://water.usgs.gov/osw/

For more information on the USGS - the Federal source for science about the Earth, its natural and living resources, natural hazards, and the environment—visit http://www.usgs.gov or call 1-888-ASK-USGS.

For an overview of USGS information products, including maps, imagery, and publications, visit http://store.usgs.gov.

Any use of trade, firm, or product names is for descriptive purposes only and does not imply endorsement by the U.S. Government.

Although this information product, for the most part, is in the public domain, it also may contain copyrighted materials as noted in the text. Permission to reproduce copyrighted items must be secured from the copyright owner.

Suggested citation:

Holmes, R.R., Jr., Koenig, T.A., Rydlund, P.H., and Heimann, D.C., 2016, Examination of flood characteristics at selected streamgages in the Meramec River Basin, Eastern Missouri, December 2015-January 2016: U.S. Geological Survey Open-File Report 2016-1140, 7 p., http://dx.doi.org/10.3133/ofr20161140. 